\title{
An Analysis of Energy Use and Estimation of a Mechanization Index of Garlic Production in Iran
}

\author{
Naeimeh Samavatean (Corresponding author) \\ Department of Agricultural Machinery Engineering \\ Faculty of Agricultural Engineering and Technology, University of Tehran \\ P.O. Box 4111, Karaj 31587-77871, Iran \\ Tel: 98-261-280-8138Ｅ-mail: na.samavatean@gmail.com \\ Shahin Rafiee \\ Department of Agricultural Machinery Engineering \\ Faculty of Agricultural Engineering and Technology, University of Tehran \\ P.O. Box 4111, Karaj 31587-77871, Iran \\ Tel: 98-261-280-8138Ｅ-mail: shahinrafiee@ut.ac.ir \\ Hossein Mobli \\ Department of Agricultural Machinery Engineering \\ Faculty of Agricultural Engineering and Technology, University of Tehran \\ P.O. Box 4111, Karaj 31587-77871, Iran \\ Tel: 98-261-280-8138Ｅ-mail: hmobli@ut.ac.ir
}

Received: September 19, 2010 Accepted: October 12, 2010 doi:10.5539/jas.v3n2p198

The research is financed by Department of Agricultural Machinery Engineering, University of Tehran, Karaj, Iran.

\begin{abstract}
This paper studies the energy balance between the input and the output per unit area for garlic in Hamedan province of Iran. In this study, data were collected by using random sampling method for 136 face to face questioners. Results showed that the highest share of energy consumption belongs to chemical fertilizers (41.7\%) followed by diesel (13.94\%). The results indicated that a total energy input of $40307.89 \mathrm{MJ} \mathrm{ha}^{-1}$ was consumed for garlic production. The energy productivity and net energy value were estimated as $0.416 \mathrm{~kg} \mathrm{MJ}^{-1}$ and-13477.82 $\mathrm{MJ} \mathrm{ha}^{-1}$, respectively. The ratio of energy outputs to energy inputs was approximately 0.665 . The benefit-cost ratio was estimated as 1.36.mechanization degree (MD) was calculated for plowing and disk border were $100 \%$ and $20.65 \%$, as the highest and lowest, respectively. The farms of between two to three hectares with 0.89 highest mechanization index (MI) and those Between one to two hectare with 0.6 lowest MI were remarkable.
\end{abstract}

Keywords: Energy ratio, Economic productivity, Mechanization Degree, Hamedan

\section{Introduction}

Garlic (Allium sativum) is classified under Alliaceae family (Takhtajan, 1997) and is widely consumed for its culinary and medical benefits. Garlic is a relatively good source of calcium, phosphorus, and potassium. Garlic is said to contain antibiotic substances that inhibit the growth of certain bacteria and fungi (Williams, 2004). Recent publications have shown the importance of the garlic as a global food crop, ranking fourth among other crops with an overall annual production of nearly 327 million tonnes and about 19 million hectares planted. China, India, Republic of Korea and United States are the main Garlic producer countries. Based on FAO 
statistics, Iran is the eighteenth producer in world. Iran produced about 70,000 tonnes of garlic in 2005, more than $65 \%$ of which was produced in Hamedan province (Food and Agriculture Organization (FAO); 2005).

Nowadays, agricultural sector has become more energy-intensive in order to supply more food to increase population and provide sufficient and adequate nutrition. However, considering limited natural resources and the impact of using different energy sources on environment and human health, it is substantial to investigate energy use patterns in agriculture. Modernization of these operations increases the energy consumption of agricultural production (Mandel et al., 2002). In order to sustain agricultural production, effective energy use in agriculture is required, since it provides financial savings, preservation of fossil resources and reduction of airs (Pimentel, 1980). Therefore, research efforts have emphasized energy and economic analysis of various agricultural productions for planning resources in the ecosystem (Singh et al., 2002). Although many experimental works have been conducted on energy use in agriculture such as wheat, maize, sugar beet, grape in Italy(Triolo et al.,1987) cotton in Greece (Tsatsarelis, 1991) stake-tomato (Esengun et al., 2007), cotton (Yilmaz et al., 2005), sugar beet (Erdal et al., 2007) and vegetable(Canakci et al., 2006; Ozkan et al. 2004) in Turkey, wheat (Safa and Tabatabaeefar, 2002; Shahan et al., 2008), cucumber (Mohammadi and Omid, 2010), barley (Ghasemi Mobtaker etal., 2010), apple (Rafiee et al., 2010) and potato(Mohammadi et al., 2008) in Iran, onion and corn in USA(Moore, 2010), peri-urban horticulture in Colombia(Bojaca and Schrevens,2010), corn in Germany(Kraatz et al., 2009). There can be found no research about garlic. singh et al., 2006 estimated a Mechanization Index and its impact on Production and Economic Factors in India. However, no studies have been published on the mechanization index analysis of garlic production in Iran.

The aims of this study were to determine input-output energy use in garlic production to investigate the efficiency of energy consumption and to make an economic analysis in garlic production. The study also sought to estimate mechanization degree in garlic production and a mechanization index based on energy factors and impact of mechanization index on energy efficiency in garlic production in Hamedan province, Iran.

\section{Materials and methods}

The study was carried out in 136 garlic producer in Hamedan province. The province is located in the west of Iran, within $49^{\circ} 35^{\prime}$ and $59^{\circ} 33^{\prime}$ north latitude and $34^{\circ} 47^{\prime}$ and $34^{\circ} 49^{\prime}$ east longitude. The total area of the Hamedan province is $1,949,300$ ha, and the farming area is 845,000 ha with a share of $43.35 \%$ (Anonymous, 2005). Data were collected from the farmers by using a face-to-face questionnaire performed from September 2008 to January 2009. Information was sought on inputs used for production of garlic as well as economic characteristics of the farms. The sample size was determined using Cochran technique as 130 farms (Snedecor and Cochran, 1989)and increased to 136 to improve accuracy. Based on the energy equivalents of the inputs and outputs (Table 1), the energy ratio (energy use efficiency), energy productivity and the specific energy were calculated (Mohammadi and Omid, 2010).

Energy use efficiency $=$ Energy output $\left(\mathrm{MJ} \mathrm{ha}^{-1}\right) /$ Energy input $\left(\mathrm{MJ} \mathrm{ha}^{-1}\right)$

Energy productivity $=$ Garlic output $\left(\mathrm{kg} \mathrm{ha}^{-1}\right) /$ Energy input $\left(\mathrm{MJ} \mathrm{ha}^{-1}\right)$

Specific energy $=$ Energy input $\left(\mathrm{MJ} \mathrm{ha}^{-1}\right) /$ Garlic output $\left(\mathrm{kg} \mathrm{ha}^{-1}\right)$

Net energy $=$ Energy output $\left(\mathrm{MJ} \mathrm{ha}^{-1}\right)-$ Energy Input $\left(\mathrm{MJ} \mathrm{ha}^{-1}\right)$

Energy intensiveness $=$ Energy Input $\left(\mathrm{MJ} \mathrm{ha}^{-1}\right) /$ Cost of cultivation $\left(\$ \mathrm{ha}^{-1}\right)$

Table 1, here

Energy requirements in agriculture are divided into two groups, direct and indirect. In this study, direct energy includes human labor, diesel, water for irrigation and indirect energy includes seeds, fertilizers, manure, chemicals, machinery. Also, non-renewable energies include diesel, electricity, chemical, fertilizers and machinery. (Except human energy, seed energy and farmyard manure energy) while human energy, seed energy and farmyard manure were considered as renewable energies.

The energy output of these systems includes main yields. The economic inputs of these systems include costs of human labor, chemical fertilizers, chemicals, hired machinery, seed, hired land and packaging, fixed costs and agricultural machinery. The economic output of these systems includes main yields, and the economic analysis include ratio of total income to total expenses.

Degree of mechanization (MD) is the index which examines the quantity in mechanization problems and is defined as the mechanized performances to total needed mechanized performances or the area in which the mechanized performances are applied to the total area. Regarding specifically, we can consider the mechanization degree as a quantity index comparable with different levels of mechanization degree. This index 
has a wide application in the growth of mechanization in different years or in comparing the mechanization degree of different operations along with great influence on analyzing the causes (Almassi et al., 2005).

Singh et al., 2006 presented a definition for mechanization index based on using living thing and machine in input energy which is calculated from relationship (1)

$$
\mathrm{Im}=\mathrm{CEM} /(\mathrm{CEH}+\mathrm{CEA}+\mathrm{CEM})
$$

Im: mechanization index, CEM: Cost of using machine, CEH: Cost of manpower, CEA: Cost of using animal power. In this research, mechanization index has been redefined as the machine and fuel energy divided by the sum of fuel and machine energy as well as animal and manpower energy (Eq. 2)

$$
\mathrm{MI}=\mathrm{E}_{\mathrm{d}} /\left(\mathrm{E}_{\mathrm{d}}+\mathrm{E}_{\mathrm{h}}+\mathrm{E}_{\mathrm{a}}\right)
$$

Mechanization index (MI) is the ratio of machinery energy (including fuel energy and machinery energy $\left(\mathrm{E}_{\mathrm{d}}\right)$ ) to the sum of machinery and fuel $\left(\mathrm{E}_{\mathrm{d}}\right)$, animal $\left(\mathrm{E}_{\mathrm{a}}\right)$ and human energy $\left(\mathrm{E}_{\mathrm{h}}\right)$. It shows what contribution machinery energy has allocated to itself in garlic cultivation in used active energy. The higher value of this index towards one show that most operations are done by machinery indicating that the higher level of mechanization has been utilized. This determination shows what level of mechanization is effective in energy consumption or how unreasonable it is to use machinery.

\section{Results and Discussion}

In this study, data used were collected from 136 garlic producers in Hamedan province. Average farm size was 1.5 ha with a range from 0.2 up to 6 ha, and $100 \%$ of total land in each farm was irrigated and about $55 \%$ of selected farms were privately owned and $45 \%$ rented.

\subsection{Analysis of input-output energy use in garlic production}

The yield in garlic farms is generally carried out by human labor energy in the research area and the number of large farms for planting and harvesting using modern technology is very limited. The results revealed that $1397.21 \mathrm{~h}$ of human power and $32.62 \mathrm{~h}$ of machine power are required per hectare of garlic production in the research area. The majority of human labor in the farms was used in the harvest (39\%) and planting (22\%) operations. The source of human labor in the surveyed farms is from either family members or mainly from hired (seasonal) labors. Share of family labor and hired human labor in garlic production was $14 \%$ and $86 \%$, respectively. Also, $1108.63 \mathrm{MJ} \mathrm{ha}^{-1}$ of diesel fuel was consumed for machinery purposes. Machinery power was used for land preparation (in all farms), and fertilizing, planting and harvesting (in many farms) and most of the machineries are mainly provided by rent. Approximately, $60 \%$ of this total diesel fuel was spent for preparation and $16 \%$ planting and the remaining (24\%) was spent by other operations such as harvesting, hoeing and spraying operations and transportation. Table 2 shows the inputs used and output in garlic production in the area of survey, and their energy equivalents with output energy rates and their equivalents are illustrated. As can be seen from Table 2, the total energy used in various farm inputs is $40307.89 \mathrm{MJ} \mathrm{ha}^{-1}$. The last column in Table 2 gives the percentage share of each input from the total energy inputs. Of all the inputs, chemical fertilizer has the largest share $41.72 \%$, in that nitrogen $(33.41 \%)$ was in the first place followed by potassium $(6.58 \%)$ and phosphate $(1.73 \%)$. chemical fertilizer is followed by the diesel energy. The diesel energy was mainly utilized for operating tractors. Diesel energy was accounted for $13.94 \%$ of total energy inputs. The percentage of energy input of seed, farm yard manure, water for irrigation, human labor, machinery and chemicals used for garlic growing were $13.77 \%, 8.77 \%, 7.40 \%, 6.79 \%$ and $2.52 \%$, respectively. In a similar study in Turkey, in tomato, pepper, cucumber and eggplant cultivation carried out by fuel and fertilizers (mainly $\mathrm{N}$ ) accounted for most of total energy inputs (Ozkan et al., 2004). In Iran in wheat, chemical fertilizers, fuel and machinery accounted for around $31.19 \%, 26.05 \%$, respectively (Safa and Tabatabaeefar, 2002) and in potato chemical fertilizers and fuel were calculated $40.17 \%$ and $15.80 \%$ respectively (Mohammadi et al., 2008).

Table 2, here

The energy use efficiency, energy productivity, specific energy, net energy and energy intensiveness of garlic production were presented in Table 3. Energy use efficiency (energy ratio) was calculated as 0.66 , showing the inefficiency use of energy in the garlic production. It is concluded that the energy ratio can be increased by raising the crop yield and/or by decreasing energy input consumption. Similar results such as 0.74 for cotton (Yilmaz et al., 2005), 1.25 for potato (Mohammadi et al., 2008), 2.86 for barley Ghasemi Mobtaker et al., 2010), 0.76 for cucumber, 0.61 for eggplant, 0.99 for pepper (Ozkan et al., 2004) have been reported for different crops. The average energy productivity of garlic was $0.41 \mathrm{~kg} \mathrm{MJ}^{-1}$. This means that 0.41 units output was obtained per unit energy. The specific energy, net energy and energy intensiveness of garlic production were $2.403 \mathrm{MJ} \mathrm{kg}-1$, $-13477.82 \mathrm{MJ}$ ha-1 and 3.85 MJ $\$^{-1}$, respectively. Net energy is negative (less than zero). Therefore, it can be 
concluded that in garlic production, energy is being lost. Similar results obtain $1.5 \mathrm{MJ} \mathrm{kg}^{-1}$ and $2.6 \mathrm{MJ} \mathrm{kg}^{-1}$ for the specific energy of corn production (Kraatz et al., 2009).

Table 3, here

Total mean energy input as direct, indirect, renewable and nonrenewable forms is given in Table 4. The total energy input consumed could be classified as direct energy (28.13\%), indirect energy (71.87\%) and renewable energy $(15.56 \%)$ and non-renewable energy $(84.44 \%)$. Several researchers showed that for potato in Iran indirect energy $(82.35 \%)$ is higher than that of direct energy $(17.65 \%)$, and non-renewable energy $(74.27 \%)$ is greater than that of renewable energy (25.73\%) (Ghasemi Mobtaker et al., 2010) And for cotton in Turkey the ratio of indirect energy is higher than that of direct energy and the rate of non-renewable energy is greater than that of renewable energy consumption (Yilmaz et al., 2005)

Table 4, here

\subsection{Economic analysis of garlic production}

The costs of each input used and calculated gross production values for garlic production are given in Table 5 . The gross value of production $\left(9489.46 \$ \mathrm{ha}^{-1}\right)$ was found by multiplying the garlic yield $\left(16768.8 \mathrm{~kg} \mathrm{ha}^{-1}\right)$ by garlic price $\left(0.56 \$ \mathrm{~kg}^{-1}\right)$. The total mean expenditure for the production was $6969.11 \$ \mathrm{ha}^{-1}$. About $95 \%$ of the total expenditure was variable costs, whereas $5 \%$ was fixed expenditure. Several studies reported that the ratio of variable cost was higher than that of fixed cost in cropping systems (Esengun et al., 2007, Cetin and Vardar, 2008). Based on these results, the benefit-cost ratio from garlic production in the farms was calculated to be 1.36. These results are consistent with the findings reported by other authors, such as 1.83 and 2.21 for greenhouse and open-field grape (Ozkan et al., 2007) and 1.10 for soybean, 2.03 for wheat, 1.98 for mustard and 2.30 for chickpea (Mandal et al., 2002), 2.58 and 1.88 for cucumber and potato, respectively (Mohammadi et al., 2008, Mohammadi and Omid, 2010$)$. The gross return $\left(2868.81 \$ \mathrm{ha}^{-1}\right)$ was calculated by subtracting the variable cost of production per hectare $\left(6620.65 \$ \mathrm{ha}^{-1}\right)$ from the gross value of production $\left(9489.46 \$ \mathrm{ha}^{-1}\right)$. The productivity $\left(2.41 \mathrm{~kg} \mathrm{\$}^{-1}\right)$ was obtained by dividing garlic yield $\left(16768.8 \mathrm{~kg} \mathrm{ha}^{-1}\right)$ by total production costs $\left(6969.11 \$ \mathrm{ha}^{-1}\right)$.

Table 5, here

\subsection{Analysis of Mechanization Degree (MD) and Mechanization Index (MI) in garlic production}

Table 6 shows the rate of MD in percent in each of machinery operations in garlic cultivation in different levels, separately.

As seen, the greatest mechanization degree relates to Moldboard plow. All the plowing operations are $100 \%$ in the site under study. This expresses that the $100 \%$ of operations were performed by machinery for garlic production for 176.65 hectares. Then, the operations of rotary hoe, lump breaking, cultivation and harvesting are done. The larger lands (over three hectares) had the highest mechanization degree (Except sprayer because using of dip irrigation) which was due to frequently using machinery and lands below one hectare had lowest M.D (table 6).

Table 6, here

Results of table 7 show that MI is obtained 0.77 for garlic production in region. Lands of between two to three hectares had The highest MI (0.93) because used least human labor energy in hectare, following by lands of least than one hectares (0.86), These lands did not have the lowest energy efficiency and fuel consumption which shows that despite the less machinery implementations, the fuel consumption was over than required level. Land of greater than three hectares $(0.74)$ and lands of between one to two hectares (0.6) had least MI. Similar study has reported that even though $78.5 \%$ farm power was contributed by mechanical and electrical power sources, the MI at an all-India level was only $14.5 \%$, and it varied from $8.2 \%$ in sorghum and paddy to a highest value of $29.00 \%$ in wheat (Singh, 2006).

Table 7, here

As seen, the effect of MI in three levels (0.01-0.3, 0.3-0.6, and 0.6-1) and land size on energy efficiency has been significant in the level of one percent. the levels of MI 0.01 to 0.3 has the least energy efficiency $(0.57)$ while it is highest for level of 0.6 to $1(0.77)$.There is no significant difference between mechanization index 0.01 to 0.3 and 0.3 to 0.6 in the level of $5 \%$ ( table 8 ). Results showed that when machinery is used in land area under one hectare, the energy efficiency increases. Using machinery causes the performance to increase. At present, a few farmers use this mechanical cultivation method.

The results of determining the effect of MI in three levels $(0.01-0.3,0.3-0.6$, and 0.6-1) on economical performance showed that the MI is significant in the level of one percent. The greatest economical performance 
1.95 has occurred in the lands with MI over 0.6 and levels of MI 0.01 to 0.3 has the least economic performance 0.94 (table 8 ). This shows that although using machine is costly and increase energy consumption, it presents a reasonable performance through machinery, influence on the time and efficiency in agriculture.

Table 8, here

\section{Conclusions}

In this study, energy use of inputs and output in garlic production in Hamedan province of Iran was determined. Garlic production consumed a total of $40307.89 \mathrm{MJ} \mathrm{ha}^{-1}$ energy and energy output was calculated as 26830.07 $\mathrm{MJ} \mathrm{ha}^{-1}$. The results revealed that chemical fertilizer (41.7\%) was the major contributor of total energy use in garlic production. The output-input ratio was calculated as 0.665 . Results show that the ratio of direct energy and non-renewable energy was higher than that of indirect energy and renewable energy. The benefit-cost ratio was found to be 1.36. The mean net return from garlic production was obtained as $2520.35 \$ \mathrm{ha}^{-1}$. The human labor energy was mainly used for harvesting, irrigating, planting and fertilizing in garlic operations. Results revealed that harvesting and planting operations are the most expensive operations with $70 \%$ for labor expenses as the highest.

MD was calculated for different operations of garlic production while plowing and disk border were $100 \%$ and $20.65 \%$ of MD, as the highest and lowest, respectively. The farms of between two to three hectares whit 0.89 highest MI and those between one to two hectare with 0.6 lowest MI were remarkable. Also, 0.77 was obtained for defined MI. the results showed that the energy efficiency and economical performance will improve whit the increase of MI.

It is recommended that educational opportunities are provided to farmers for changing their wrong behaviors and the controlled input use is employed by performance monitoring. Application of integrated pest management and assessment studies can be suggested to improve energy efficiency. This is the responsibility of local and regional policy planning and implementation by decision making authorities. Inputs for mechanization require long-term investment for creating support services infrastructure for manufacture, marketing, after-sale service network, training, demonstration, and credit support. The Government must take adequate measures to promote mechanization by providing financial incentives to the farmers and to the farm machinery industries to manufacture quality farm machinery.

\section{References}

Almassi, M., Kiani, Sh \& Loveimi, N. (2005). Principles of Agricultural Mechanization (3th ed).Gom: Hazrate Masoomeh. (In Prersian)

Anonymous. (2005). Annual Agricultural Statistics. Ministry of Jihad-e-Agriculture of Iran. [Online] Available: www.maj.ir.

Bojaca, C.R \& Schrevens, E. (2010). Energy assessment of peri-urban horticulture and its uncertainty: case study for Bogota, Colombia. Energy, 35(5), 2109-2118.

Canakci M \& Akinici I. (2006). Energy use pattern analyses of greenhouse vegetable production. Energy, 31, $1243-1256$

Cetin B \& Vardar A. (2008). A conomic analysis of energy requirements and input costs for tomato production in Turkey, Renew Energy, 33, 428-433.

Erdal G, Esengun K, Erdal H \& Gunduz O. (2007). Energy use and economical analysis of sugar beet production in Tokat province of Turkey. Energy, 32,35-41.

Esengun K, Erdal G, Gunduz O \& Erdal H. (2007). An economic analysis and energy use in stake-tomato production in Tokat province of Turkey. Renew Energy, 32,1873-81.

Food and Agriculture Organization (FAO). (2005). [Online] Available: www.fao.org.

Ghasemi Mobtaker H, Keyhani A, Mohammadi A, Rafiee SH \& Akram A. (2010). Sensitivity analysis of energy inputs for barley production in Hamedan Province of Iran, Agriculture, Ecosystems and Environment, 137, $367-372$

Hetz E. (1998). Energy utilization in fruit production in Chile. Agricultural Mechanization in Asia, Africa, and Latin America, 29(2),17-20.

Kraatz, S, Reinemann, D.J \& Berg, W.E. (2009). Energy inputs for corn production in Wisconsin (U.S.) and Germany. Applied Engineering in Agriculture, 25, 653-662. 
Mandal K.G., Saha K.P., Ghosh PK, Hati K.M \& Bandyopadhyay K.K. (2002). Bioenergy and economic analysis of soybean-based crop production systems in central India. Biomass Bioenergy, 23(5),337-45.

Mohammadi A, Tabatabaeefar A, Shahin S., Rafiee S \& Kyhani A. (2008). Energy use and economical analysis of potato production in iran a case study: Ardabil province, Energy Convers Manage, 49,3566-3570.

Mohammadi A \& Omid M. (2010). Economical analysis and relation between energy inputs and yield of greenhouse cucumber production in Iran, Appl Energy, 87,191-196.

Moore, S.R. (2010). Energy efficiency in small-scale biointensive organic onion production in Pennsylvania, USA. Renewable Agriculture and Food Systems, in press. doi:10.1017/S1742170510000098, http://dx.doi.org/10.1017/S1742170510000098

Ozkan B., Kurklu A \& Akcaoz H. (2004). An input--output energy analysis in greenhouse vegetable production: a case study for Antalya region of Turkey. Biomass Bioenergy, 26, 189-95.

Pimentel D. (1980). Handbook of energy utilization in agriculture. Boca Raton, FL: CRC Press;.

Rafiee S, Mousavi avval SH, Mohammadi A. (2010). Modeling and sensitivity analysis of energy inputs for apple production in Iran. Energy, 35(8), 3301-3306.

Safa M \& Tabatabaeefar A. (2002). Energy consumption in wheat production in irrigated and dry land farming. In: Proc. Intl. Agric. Eng. Conf., Wuxi, China, November 28-30;

Shahan S., jafari A., Mobli H., Rafiee S \& Karimi M. (2008). Energy use and economical analysis of wheat production in iran: a case study from Ardabil province, J. Agricultural Technology, 4, 77-88.

Singh H., Mishra D \& Nahar N.M. (2002). Energy use pattern in production agriculture of a typical village in arid zone India-Part I. Energy Conversion Manage, 43,2275-86

Singh G. (2006). Estimation of a Mechanization Index and Its Impact on Production and EconomicFactors-a Case Study in India. Biosystems Engineering, 93(1), 99-106.

Singh S \& Mittal J.P. (1992). Energy in production agriculture. Mittol Pub. New Delhi.

Snedecor G.W \& Cochran W.G. (1989). Statistical Methods. 8th edn. Iowa State Press, USA.

Takhtajan A. (1997). Diversity and Classification of Flowering Plants, 13rd edn. New York, Columbia University Press.

Triolo L., Unmole H., Mariani A \& Tomarchio L. (1987). Energy analyses of agriculture: the Italian case study and general situation in developing countries. In: Third international symposium on mechanization and energy in agriculture, Izmir, Turkey, October 26-29, 172-84.

Tsatsarelis CA. (1991). Energy requirements for cotton production in central Greece. J. Agric Eng Res, 50, $239-46$.

Williams, A (2004) garlic, UK, Great Britain.

Yilmaz I., Akcaoz H \& Ozkan B. (2005). An analysis of energy use and input costs for cotton production in Turkey. Renew Energy,30, 145-55. 
Table 1. Energy equivalents of inputs and output in agricultural production

\begin{tabular}{|l|c|c|l|}
\hline \multicolumn{1}{|c|}{ Particulars } & Unit Energy & Equivalent $\left(\mathbf{M J ~ u n i f ~}^{-1}\right.$ ) & \multicolumn{1}{c|}{ Ref. } \\
\hline A. Inputs & & & (Mohammadi and Omid, 2010) \\
\hline 1. Human labor & $\mathrm{h}$ & 1.96 & (Singh et al., 2002, Canakci et al., 2005) \\
\hline 2. Machinery & $\mathrm{h}$ & 62.7 & (Hetz, 1998) \\
\hline 3. Diesel fuel & $\mathrm{L}$ & 47.8 & \\
\hline 4. Chemical fertilizers & $\mathrm{kg}$ & & (Erdal et al., 2007, Cetin and Vardar, 2008) \\
\hline (a) Nitrogen $(\mathrm{N})$ & & 66.14 & (Erdal et al., 2007, Cetin and Vardar, 2008) \\
\hline (b) Phosphate $\left(\mathrm{P}_{2} \mathrm{O}_{5}\right)$ & & 12.44 & (Erdal et al., 2007, Cetin and Vardar, 2008) \\
\hline (c) Potassium $\left(\mathrm{K}_{2} \mathrm{O}\right)$ & & 11.15 & (Ghasemi Mobtaker et al., 2010) \\
\hline 5. Farmyard manure & $\mathrm{kg}$ & 0.30 & (Ghasemi Mobtaker et al., 2010) \\
\hline 6. Chemicals & $\mathrm{kg}$ & 120 & (Mohammadi and Omid, 2010) \\
\hline 7. Water for irrigation & $\mathrm{m}^{3}$ & 1.02 & (Singh and Mittal, 1992) \\
\hline 9. Seeds (garlic) & $\mathrm{kg}$ & 1.6 & \\
\hline B. Outputs & & & (Singh and Mittal, 1992) \\
\hline 1. Garlic & $\mathrm{kg}$ & 1.6 &
\end{tabular}

Table 2. Amounts of inputs, output and energy inputs and output in garlic production

\begin{tabular}{|l|l|c|c|c|}
\hline $\begin{array}{c}\text { Quantity (inputs and } \\
\text { outputs) }\end{array}$ & unit & $\begin{array}{c}\text { Quantity per unit } \\
\text { area (ha) }\end{array}$ & $\begin{array}{c}\text { Total energy equivalente } \\
\left(\text { MJ ha }^{-1}\right)\end{array}$ & $\begin{array}{c}\text { Percentage of the } \\
\text { total (\%) }\end{array}$ \\
\hline A. Inputs & & & & 6.79 \\
\hline 1. Human labor & $(\mathrm{h})$ & 1397.21 & 2738.52 & 5.07 \\
\hline 2. Machinery & $(\mathrm{h})$ & 32.62 & 2045.48 & 13.94 \\
\hline 3. Diesel fuel & $(\mathrm{L})$ & 157.39 & 5620.72 & 33.41 \\
\hline 4. Chemical fertilizers) & $(\mathrm{kg})$ & 479.37 & & 1.73 \\
\hline (a) Nitrogen $(\mathrm{N})$ & & 203.62 & 13467.61 & 6.58 \\
\hline (b) Phosphate( $\left.\mathrm{P}_{2} \mathrm{O}_{5}\right)$ & & 213.20 & 697.54 & 2.77 \\
\hline (c) Potassium $\left(\mathrm{K}_{2} \mathrm{O}\right)$ & & 62.55 & 2652.21 & 7.40 \\
\hline 5. Farmyard manure & $(\mathrm{kg})$ & 11925.7 & 3537.0 & 13.77 \\
\hline 6. Chemicals & $(\mathrm{kg})$ & 7.85 & 1016.09 & 100 \\
\hline 7. Water for irrigation & $\left(\mathrm{m}^{3}\right)$ & 2925.59 & 2984.11 & \\
\hline 8. Seeds (garlic) & $(\mathrm{kg})$ & 3265.95 & 5548.61 & \\
\hline Total energy input & $(\mathrm{MJ})$ & & 40307.89 & \\
\hline B. Outputs & & & & \\
\hline 1. Garlic & $(\mathrm{kg})$ & 16768.8 & 26830.07 & \\
\hline
\end{tabular}

Table 3. Energy input-output ratio in garlic production

\begin{tabular}{|l|c|c|}
\hline Items & \multicolumn{1}{|c|}{ Unit } & Garlic \\
\hline Energy input & $\mathrm{MJ} \mathrm{ha}^{-1}$ & 40307.89 \\
\hline Energy output & $\mathrm{MJ} \mathrm{ha}^{-1}$ & 26830.07 \\
\hline Yield & $\mathrm{kg} \mathrm{ha}^{-1}$ & 16768.8 \\
\hline Energy use efficiency & - & 0.665 \\
\hline Specific energy & $\mathrm{MJ} \mathrm{kg}^{-1}$ & 2.403 \\
\hline Energy productivity & $\mathrm{kg} \mathrm{MJ}^{-1}$ & 0.416 \\
\hline Net energy & $\mathrm{MJ} \mathrm{ha}^{-1}$ & -13477.82 \\
\hline Energy intensiveness & $\mathrm{MJ} \mathrm{\$}^{-1}$ & 3.85 \\
\hline
\end{tabular}


Table 4. Total energy input in the form of direct, indirect, renewable and non-renewable for garlic production $\left(\mathrm{MJ} \mathrm{ha}^{-1}\right)$

\begin{tabular}{|l|c|c|}
\hline Form of energy $^{\left(M_{J} \text { ha }^{-1}\right)}$ & Garlic & $\boldsymbol{\%}^{\boldsymbol{e}}$ \\
\hline Direct energy $^{\mathrm{b}}$ & 11343 & 28.14 \\
\hline Indirect energy $^{\mathrm{c}}$ & 28965 & 71.85 \\
\hline Renewable energy $^{\mathrm{d}}$ & 14808 & 36.73 \\
\hline Non-renewable energy $^{\mathrm{e}}$ & 25499.65 & 63.26 \\
\hline
\end{tabular}

a Includes human labor, diesel, water for irrigation, electricity.

${ }^{\mathrm{b}}$ Includes seeds, fertilizers, manure, chemicals, machinery.

${ }^{\mathrm{c}}$ Includes human labor, seeds, manure, water for irrigation.

${ }^{\mathrm{d}}$ Includes diesel, electricity, chemical, fertilizers, machinery.

${ }^{\mathrm{e}}$ Indicates percentage of total energy input.

Table 5. Economic analysis of garlic production

\begin{tabular}{|l|l|l|}
\hline Cost and return components & Unit & Value \\
\hline Yield & $\mathrm{kg} \mathrm{ha}^{-1}$ & 16768.8 \\
\hline Sale price & $\$ \mathrm{~kg}^{-1}$ & 0.5659 \\
\hline Gross value of production & $\$ \mathrm{ha}^{-1}$ & 9489.46 \\
\hline Variable cost of production & $\$ \mathrm{ha}^{-1}$ & 6620.65 \\
\hline Fixed cost of production & $\$ \mathrm{ha}^{-1}$ & 348.45 \\
\hline Total cost of production & $\$ \mathrm{ha}^{-1}$ & 6969.11 \\
\hline Total cost of production & $\$ \mathrm{~kg}^{-1}$ & 0.415 \\
\hline Gross return & $\$ \mathrm{ha}^{-1}$ & 2868.81 \\
\hline Net return & $\$ \mathrm{ha}^{-1}$ & 2520.35 \\
\hline Benefit to cost ratio & - & 1.36 \\
\hline Productivity (only main) & $\mathrm{kg} \mathrm{\$}^{-1}$ & 2.41 \\
\hline
\end{tabular}

Table 6. Share of MD to total operations in garlic production

\begin{tabular}{|l|l|l|l|l|l|}
\hline Machine operations & $<\mathbf{1}$ & $\mathbf{1}-<\mathbf{2}$ & $\mathbf{2}-<\mathbf{3}$ & $\geq \mathbf{3}$ & total \\
\hline Moldboard plow & 100 & 100 & 100 & 100 & 100 \\
\hline lump breaking & $7.6^{\mathrm{a}}$ & $10^{\mathrm{a}}$ & $48^{\mathrm{b}}$ & $72.7^{\mathrm{c}}$ & 34.55 \\
\hline Rotary hoe & $38.2^{\mathrm{a}}$ & $26.6^{\mathrm{a}}$ & $52^{\mathrm{a}}$ & $90.9^{\mathrm{b}}$ & 49.87 \\
\hline Disk border & $15^{\mathrm{ab}}$ & $23.3^{\mathrm{ab}}$ & $8^{\mathrm{a}}$ & $36.3^{\mathrm{b}}$ & 20.56 \\
\hline Fertilizer distributor & $12.8^{\mathrm{a}}$ & $13.3^{\mathrm{a}}$ & $20^{\mathrm{ab}}$ & $36.3^{\mathrm{b}}$ & 21.15 \\
\hline Planter machine & $7.6^{\mathrm{a}}$ & $11.6^{\mathrm{a}}$ & $56^{\mathrm{b}}$ & $63.6^{\mathrm{b}}$ & 34.67 \\
\hline sprayer & $27^{\mathrm{a}}$ & $28.3^{\mathrm{a}}$ & $20^{\mathrm{a}}$ & $9^{\mathrm{a}}$ & 21.07 \\
\hline Harvester machine & $20^{\mathrm{a}}$ & $20^{\mathrm{a}}$ & $28^{\mathrm{a}}$ & $54^{\mathrm{b}}$ & 30.5 \\
\hline
\end{tabular}

Table 7. Mechanization Index for different land size

\begin{tabular}{|l|l|l|l|l|l|}
\hline & $<\mathbf{1}$ & $\mathbf{1 - 2}$ & $\mathbf{2 - 3}$ & $\mathbf{3}$ & total \\
\hline Mechanization index & $0.86^{\mathrm{bc}}$ & $0.60^{\mathrm{a}}$ & $0.89^{\mathrm{c}}$ & $0.74^{\mathrm{b}}$ & 0.77 \\
\hline Number of farmers & 40 & 60 & 25 & 11 & 136 \\
\hline
\end{tabular}

Table 8. Economic performance and Energy efficiency for different Mechanization Index levels

\begin{tabular}{|l|l|l|l|}
\hline $\boldsymbol{M I}$ & $\mathbf{0 . 0 1 - 0 . 3}$ & $\mathbf{0 . 3 - 0 . 6}$ & $\mathbf{0 . 6}<\mathbf{1}$ \\
\hline Economic performance & $0.94^{\mathrm{a}}$ & $1.17^{\mathrm{a}}$ & $1.95^{\mathrm{b}}$ \\
\hline Energy efficiency & $0.57^{\mathrm{a}}$ & $0.65^{\mathrm{bc}}$ & $0.77^{\mathrm{c}}$ \\
\hline Number of farmers & 19 & 34 & 83 \\
\hline
\end{tabular}

